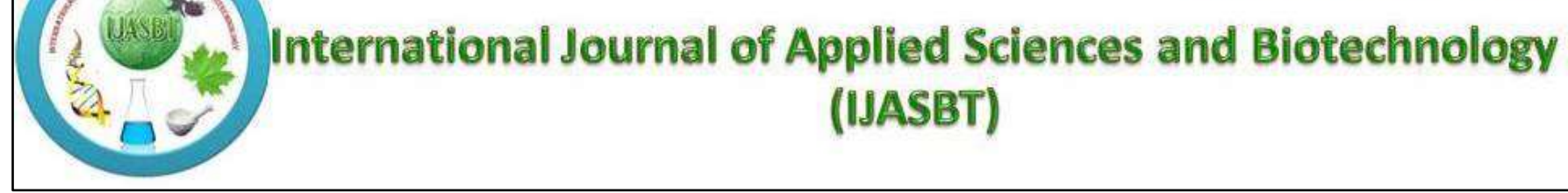

\title{
STUDY ON GENOTYPIC RESPONSE AND CORRELATION ANALYSIS OF THE YIELD AND YIELD ATTRIBUTING TRAITS OF DIFFERENT BARLEY (Hordeum vulgare) GENOTYPES
}

\author{
Deepak Vitrakoti ${ }^{1}$, Sheetal Aryal ${ }^{1}$, Santosh Rasaily ${ }^{2}$, Bishnu Raj Ojha ${ }^{2}$, Raju Kharel ${ }^{2}$, and Manoj Sapkota ${ }^{1 *}$ \\ ${ }^{1}$ Institute of Agriculture and Animal Science, Tribhuvan University, Rampur, Chitwan, Nepal \\ ${ }^{2}$ Department of Genetics and Plant Breeding, Agriculture and Forestry University, Rampur Chitwan, Nepal
}

*Corresponding author email: manoj34sapkota@gmail.com

\begin{abstract}
Barley, being a tremendous opportunities crop, we are far back regarding study, research and utilization. An experiment was conducted 20142015 to evaluate the barley genotypes for their yield attributing traits and correlation and causation. Eleven yield contributing traits viz., days to booting, heading and flowering; peduncle length, spike length, plant height, flag leaf area, flag leaf-1 area, thousand grain weight, biological weight and yield per hectare were recorded. High significant variation among genotypes was found for traits under study. Genotypes SBYT313\#1115 (1960 kg), 14-SB-NAK-MR\#17 (1760 kg) and AM POP\#26 (1660 kg) were found to be superior for their per se performance based on grain yield per hectare, yield attributing and other quantitative traits. Thousand grains weight (0.333) had positively highest significant correlation with grain yield per hectare followed by spike length (0.310). Grain yield per hectare showed negative highly significant correlation with days to flowering $(-0.796)$ followed by days to heading $(-0.761)$ and days to booting $(-0.663)$. Peduncle length $(0.229)$, plant height (0.226), biological weight $(0.181)$ and flag leaf area $(0.032)$ were positively correlated with grain yield per hectare while flag leaf-1 area(0.029) was negatively correlated. Thus, selection for genotypes with higher thousand grain weight and spike length accommodating earlier days to flowering, heading and booting is a prerequisite for attaining improvement in grain yield per hectare.
\end{abstract}

Keywords: Barley; Hordeum vulgare; yield; correlation

\section{Introduction}

Barley (Hordeum vulgare) is one of the oldest and first domesticated crop, considered to be grown even during the Stone Age (Salamini et al., 2002). Barley is the founder crop which belong to the genus Hordeum in the Triticaceae of the grass family i.e. Poaceae (Gramineae). It is a selfpollinated diploid crop with $2 n=14$. Barley is the fourth most important cereal crop in the world after wheat, maize and rice (Akar et al., 2004). Barley is among the top ten crop plants in the world (FAO, 2007). Globally, over 133 million tons of barley is produced annually on about 55.4 million hectares.

Barley (Hordeun vulgare) is considered as the fifth most important cereal crop in Nepal after rice, maize, wheat and finger millet in terms of acreage and production. Barley is a momentous crop from religious point of view in the Hindu society to worship the god. Barley (Hordeum vulgare) is one of the old and essential winter crop for the high mountain areas of the country. Large amount of diversity is observed for barley in the Nepalese high lands. The region is considered as a center of diversity for barley (Witcombe and Gilani, 1979). Barley is cultivated in a wide range of environments in Nepal (Baniya et al., 1997). The area of production of barley production is limited, but it is grown from the terai up to an elevation of $4000 \mathrm{~m}$. It is a staple food crop mainly in the hills and mountains in the west of the country. Although, the reported barley production in the terai has declined in the past decade from 6000 to 3000 tons per year, the production in the hills during the same time has increased from 9000 to 12000 tons and from 8000 to 10000 tons in the mountains (Baniya, 1989).

Barley is an annual cereal, cultivated worldwide in all temperate climate zones. It is considered as a major animal feed crop, with lower amounts used for malting and human food. Barley was one of the first domesticated cereals, thought to be originated in the Fertile Crescent in Middle East. Archaeological evidence traced date back to around 8000 BC for barley cultivation in Iran. The genetic system of the crop is simple; however, the species are genetically diverse. This makes this crop as a perfect organism as a 
cereal research model. Molecular evidence has shown significant homology among barley, wheat and rye (Feuillet et al., 2002).

Estimating the correlation among several traits, specially grain yield and its components and also the determining causal relationships gives the breeders with the needed help and criteria to select the most suitable combination of various components that will would yield better (Moradi et al., 2010).

This study mainly concerns with evaluation per se performance of genotypes, study of the nature and magnitude of association among yield traits, selection of better performing genotypes regarding the yield and yield attributing traits and also to identify the traits for the selection of high yielding traits of the barley correlation coefficient analysis.

In world, major agricultural research activities are focused on yield ignoring the quality parameters. In developing countries like Nepal, research activities are only intense in the major crop like Rice, Wheat and Maize whereas very few efforts had been made in the minor crop like Millet, Buckwheat, Barley. Barley although having major importance and many uses in the country, it is still considered as underutilized crop. But these minor crops are staple food in the upper hilly and mountain region. We are still lacking strong research focusing on nutrition aspect.

Barley, being a tremendous opportunities crop, we are far back regarding its utilization as an industrial crop. In the past decades, several breweries have been established in the country producing a number of beers brands for the local and foreign market. Malt -barley the main ingredient of beer, is however, imported by all these breweries. Barley is mainly used in beverage industries as a raw material. Efforts for the improvement in the quality and the quantity of the production is lacking. Lack of study and research is a major problem regarding this crop. Thus, this study could work as a pivotal work for the development of the crop in the country and also as a base work for the further researches regarding this crop.

\section{Materials and Methods}

The field experiment was conducted at the research field of Institute of Agriculture and Animal Science (IAAS), Rampur Campus, Chitwan in the academic year of $2014 / 2015$ from November to March. It is located at $27^{\circ} 37^{\prime}$ $\mathrm{N}$ latitude and $84^{\circ} 25^{\prime} \mathrm{E}$ longitude with an elevation of 228 meters above mean sea level. The soil type is sandy loam. The climate of research site is humid and sub-tropical with average annual rainfall of $2000 \mathrm{~mm}$ (mainly during mid to late summer). The plant materials used in research were the genotype provided by International Center for Agricultural Research in the Dry Area (ICARDA), Morocco. Two local variety Bonus and Soluwa were provided by Hill Crop Research Program (HCRP), Kabre (National Agricultural
Research Council (NARC)) (Table 1). The experiment was laid out in alpha-lattice design with 2 replications; 5 blocks within replication and 6 genotypes within block. The plot size was $2.5 \mathrm{~m} \times 1 \mathrm{~m}$ with continuous sowing in 4 rows per plot. The row to row spacing was $25 \mathrm{~cm}$, block to block spacing was $0.5 \mathrm{~m}$ and space between two replications was $1 \mathrm{~m}$. Chemical fertilizers were applied at the rate of 60:30:30 $\mathrm{Kg}$ ha-1 of Nitrogen, Phosphorus and potassium respectively. Planting was done at 1st December, 2014 manually in continuous line sowing.

Table 1: Details of plant materials (genotypes) used in research

\begin{tabular}{|c|c|c|}
\hline S.N. & Genotype & Source \\
\hline 1 & AM POP\#1 & ICARDA \\
\hline 2 & AM POP\# 4 & ICARDA \\
\hline 3 & AM POP\#5 & ICARDA \\
\hline 4 & AM POP\#10 & ICARDA \\
\hline 5 & AM POP \#18 & ICARDA \\
\hline 6 & AM POP \#19 & ICARDA \\
\hline 7 & AM POP\#25 & ICARDA \\
\hline 8 & AM POP\#26 & ICARDA \\
\hline 9 & AM POP\#38 & ICARDA \\
\hline 10 & AM POP\#48 & ICARDA \\
\hline 11 & AM POP\#56 & ICARDA \\
\hline 12 & 1st GSBYT \#112 & ICARDA \\
\hline 13 & 1st GSBYT \#113 & ICARDA \\
\hline 14 & SBYT2-13\#1215 & ICARDA \\
\hline 15 & SBYT2-13\#2216 & ICARDA \\
\hline 16 & SBYT2-13\#3106 & ICARDA \\
\hline 17 & SBYT2-13\#3313 & ICARDA \\
\hline 18 & SBYT2-13\#4701 & ICARDA \\
\hline 19 & SBYT2-13\#4909 & ICARDA \\
\hline 20 & SBYT2-13 \#5203 & ICARDA \\
\hline 21 & SBYT2-13\# 6416 & ICARDA \\
\hline 22 & SBYT3-13\#211 & ICARDA \\
\hline 23 & SBYT3-13\#417 & ICARDA \\
\hline 24 & SBYT3-13\#619 & ICARDA \\
\hline 25 & SBYT3-13\#1115 & ICARDA \\
\hline 26 & 14-SB-NAK-MR\#17 & ICARDA \\
\hline 27 & 14-SB-NAK-MR\#139 & ICARDA \\
\hline 28 & 14-SB-NAK-MR\#144 & ICARDA \\
\hline 29 & Bonus & HCRP, Kabre(NARC) \\
\hline 30 & Soluwa & HCRP, Kabre(NARC) \\
\hline
\end{tabular}


Observations were taken for days to booting, days to heading, days to flowering, area of flag leaf, area of flag leaf -1 , peduncle length, spike length, plant height, thousand grain weight, biological weight, grain yield per hectare. Five plants were tagged randomly for recording observations for each entry for all the quantitative traits except for days to booting, heading and flowering, thousand grain weight, biological weight and grain yield per hectare for which whole plant from each plot is taken into consideration.

Data entry and processing was carried out using Microsoft Office Excel 2010 software and mean and standard deviations for all quantitative traits were computed. Analysis of variance was calculated using MINITAB 14. Linear correlation was computed using SPSS.

Simple correlation coefficients were calculated for each pairs of the parameters using the formula by Steel and Torrie (1980):

$r=\frac{S P_{X}}{\sqrt{S S_{X} S S_{Y}}}$

$\mathrm{r}=$ Correlation coefficient between $\mathrm{X}$ and $\mathrm{Y}$

$\mathrm{SP}_{\mathrm{X}}=$ Sums of product

$\mathrm{SS}_{\mathrm{X}}=$ Sums of square

$\mathrm{X}=$ Independent variable

$\mathrm{Y}=$ Dependent variable

\section{Results and Discussions}

\section{Mean Value of Observed Traits}

Significant variation was found among the studied genotypes for days to booting, days to heading, days to flowering, peduncle length, spike length, flag leaf-1 area, thousand grain weight, biological weight and yield per hectare. It was non-significant for traits like plant height and flag leaf area. The mean value of all the traits observed are presented in Table 2. There are significant differences among the genotypes for all characters reported here in because of diverse genetic background of genotypes used in experiment as obtained from ICARDA and HCRP, Kabre (NARC).

Besides yield, traits like thousand grain weight and spike length were important yield contributing characters. In the experiment, SBYT3-13\#1115 showed significantly higher grain yield followed by 14-SB-NAK-MR\#17, AM POP\#26, SBYT3-13\#211, SBYT3-13\#417, AM POP\#1, SBYT2-
13\#2216, 14-SB-NAK-MR\#144 and SBYT3-13\#619. With comparison to Nepalese check variety Bonus and Soluwa, 19 genotypes give higher yield, but average Nepalese production is $1100 \mathrm{~kg} /$ hac $(2012 / 2013$, CBS), so only above mentioned nine genotypes were found superior for their performance based on grain yield per hectare.

Genotypes 14-SB-NAK-MR\#17 had the earliest days to flowering(73.14days) and days to heading (70.19days) followed by AM POP \#26 and AM POP\#1 which had grain yield per hectare of $1760 \mathrm{~kg}, 1660 \mathrm{~kg}$ and $1560 \mathrm{~kg}$ respectively. Genotypes SBYT3-13 \#211(58.5 days) showed earliest booting followed by AM POP \#1(59.5 days) and SBYT3-13\#2216 (61 days) and this trait is highly and significantly correlated with grain yield per hectare and the grain yield obtained was 1640,1560 and $1380 \mathrm{~kg}$ per hectare. Varieties with earlier days to booting can be recommended as they are superior in yield. Thus, we can say that genotypes with earlier days to flowering, days to heading and days to booting contribute significantly in improvement ingrain yield per hectare of barley. This is supported by findings from Singh et al. (1987).

\section{Correlation Coefficient Analysis}

Based on correlation coefficient of yield component and grain yield per hectare, thousand grains weight had positively highest and highly significant correlation with grain yield per hectare. There was a positive significant correlation of grain yield per hectare with spike length. Grain yield per hectare showed negative highly significant correlation with days to flowering followed by days to heading and days to booting. Peduncle length, plant height, flag leaf area and biological weight didn't differ significantly and correlated positively with grain yield per hectare while flag leaf -1 area showed negative correlation with grain yield per hectare. The pair wise simple correlation coefficients among various yield components have been presented in Table 3 and Fig. 1 (a-j).

Grain yield per hectare was negatively and highly significantly correlated with traits viz., days to flowering followed by days to heading and days to booting. Negative correlation coefficient among traits shows that the changes of two variables are in the opposite direction, i.e. high value of one variable is associated with low value of other and vice versa. However, the most yield determinative traits were days to flowering, days to heading, days to booting. Hence, the selection for these traits could be helpful in bringing an improvement in grain yield per hectare. Khayatnezhad et al. and Mohammadi also reported similarly that the maximum direct negative effect on performance was related to the days to heading. 
Table 2: Mean value of all the observed traits under study.

\begin{tabular}{|c|c|c|c|c|c|c|c|c|c|c|c|}
\hline Genotype & $\begin{array}{l}\text { Days to } \\
\text { Booting }\end{array}$ & $\begin{array}{l}\text { Days to } \\
\text { Heading }\end{array}$ & $\begin{array}{l}\text { Days to } \\
\text { Flowering }\end{array}$ & $\begin{array}{l}\begin{array}{l}\text { Peduncle } \\
\text { Length } \\
\text { (cm) }\end{array} \\
\end{array}$ & $\begin{array}{l}\text { Spike } \\
\text { Length } \\
\text { (cm) }\end{array}$ & $\begin{array}{l}\text { Plant } \\
\text { Height } \\
\text { (cm) }\end{array}$ & $\begin{array}{l}\text { Flag leaf } \\
\text { area } \\
\left(\mathrm{cm}^{2}\right)\end{array}$ & $\begin{array}{l}\text { Flag leaf -1 } \\
\text { area } \\
\left(\mathrm{cm}^{2}\right)\end{array}$ & $\begin{array}{l}\text { Thousand Grain } \\
\text { Weight } \\
\text { (gm) }\end{array}$ & $\begin{array}{l}\text { Biological } \\
\text { Weight } \\
\text { (kg) }\end{array}$ & $\begin{array}{l}\text { Yield per } \\
\text { hectare } \\
(\mathrm{kg})\end{array}$ \\
\hline AM POP \#1 & 59.50 & 70.51 & 77.60 & 26.39 & 5.54 & 84.33 & 8.84 & 15.62 & 0.05 & 1.64 & 1560 \\
\hline AM POP\# 4 & 63.50 & 77.28 & 79.91 & 26.95 & 6.25 & 78.67 & 7.51 & 18.19 & 0.04 & 1.24 & 740 \\
\hline AM POP\#5 & 71.00 & 81.78 & 85.16 & 31.60 & 7.62 & 88.08 & 8.30 & 19.61 & 0.04 & 1.82 & 880 \\
\hline AM POP\#10 & 73.00 & 85.57 & 87.47 & 25.46 & 6.44 & 85.83 & 5.51 & 14.41 & 0.06 & 2.15 & 500 \\
\hline AM POP \#18 & 76.00 & 85.61 & 89.09 & 20.98 & 4.67 & 81.00 & 7.86 & 14.99 & 0.06 & 1.69 & 435 \\
\hline AM POP \#19 & 74.50 & 88.30 & 90.14 & 23.70 & 5.17 & 101.30 & 8.78 & 22.72 & 0.05 & 1.85 & 220 \\
\hline AM POP\#25 & 71.00 & 81.85 & 82.63 & 29.61 & 8.12 & 93.17 & 7.26 & 14.53 & 0.05 & 1.45 & 680 \\
\hline AM POP\#26 & 66.00 & 72.61 & 76.09 & 31.81 & 4.84 & 100.70 & 11.56 & 14.25 & 0.05 & 1.79 & 1660 \\
\hline AM POP\#38 & 73.00 & 91.27 & 98.17 & 28.53 & 5.64 & 87.00 & 4.66 & 16.87 & 0.03 & 1.79 & 100 \\
\hline AM POP\#48 & 77.50 & 91.75 & 98.51 & 19.77 & 6.06 & 71.66 & 4.91 & 8.47 & 0.04 & 0.64 & 240 \\
\hline AM POP\#56 & 74.50 & 85.55 & 89.35 & 26.60 & 6.25 & 83.00 & 4.84 & 11.66 & 0.05 & 1.13 & 240 \\
\hline 1st GSBYT \#112 & 62.00 & 77.35 & 81.78 & 28.64 & 8.06 & 80.33 & 4.58 & 15.23 & 0.05 & 1.69 & 980 \\
\hline 1st GSBYT \#113 & 72.50 & 82.61 & 86.59 & 18.65 & 5.84 & 76.17 & 3.27 & 10.90 & 0.04 & 1.30 & 460 \\
\hline SBYT2-13\#1215 & 69.50 & 83.51 & 92.10 & 23.10 & 6.42 & 84.17 & 4.09 & 5.03 & 0.04 & 1.32 & 190 \\
\hline SBYT2-13\#2216 & 61.00 & 74.58 & 78.82 & 28.76 & 8.23 & 89.67 & 3.84 & 9.98 & 0.05 & 1.88 & 1380 \\
\hline SBYT2-13\#3106 & 64.00 & 78.35 & 81.13 & 23.45 & 6.61 & 80.83 & 9.37 & 9.03 & 0.04 & 1.42 & 800 \\
\hline SBYT2-13\#3313 & 69.50 & 83.51 & 87.10 & 26.94 & 6.03 & 88.17 & 2.93 & 6.67 & 0.03 & 1.37 & 320 \\
\hline SBYT2-13\#4701 & 84.50 & 95.75 & 100.50 & 29.10 & 4.37 & 90.00 & 8.70 & 32.04 & 0.04 & 2.43 & 140 \\
\hline SBYT2-13\#4909 & 75.50 & 84.27 & 90.67 & 16.78 & 4.67 & 64.17 & 5.33 & 13.50 & 0.05 & 1.53 & 160 \\
\hline SBYT2-13 \#5203 & 66.50 & 78.78 & 85.41 & 23.37 & 6.00 & 75.42 & 1.87 & 6.86 & 0.05 & 1.27 & 460 \\
\hline SBYT2-13\# 6416 & 71.50 & 83.78 & 89.66 & 15.60 & 9.34 & 78.17 & 2.80 & 11.19 & 0.04 & 2.34 & 560 \\
\hline SBYT3-13\#211 & 58.50 & 72.26 & 80.36 & 28.58 & 8.00 & 91.00 & 4.90 & 13.90 & 0.04 & 1.75 & 1640 \\
\hline SBYT3-13\#417 & 65.50 & 76.27 & 80.17 & 27.61 & 9.00 & 89.67 & 4.72 & 20.20 & 0.05 & 1.48 & 1640 \\
\hline SBYT3-13\#619 & 62.50 & 71.08 & 78.95 & 25.07 & 6.33 & 73.75 & 7.14 & 21.98 & 0.04 & 1.97 & 1120 \\
\hline SBYT3-13\#1115 & 66.00 & 74.27 & 77.17 & 24.20 & 6.75 & 84.58 & 3.26 & 11.30 & 0.05 & 1.50 & 1960 \\
\hline $\begin{array}{l}\text { 14-SB-NAK- } \\
\text { MR\#17 }\end{array}$ & 64.50 & 70.19 & 73.14 & 23.34 & 6.67 & 84.17 & 4.20 & 11.96 & 0.05 & 1.60 & 1760 \\
\hline $\begin{array}{l}\text { 14-SB-NAK- } \\
\text { MR\#139 }\end{array}$ & 64.00 & 79.27 & 82.67 & 31.11 & 8.83 & 98.50 & 5.05 & 16.38 & 0.04 & 1.88 & 940 \\
\hline
\end{tabular}


D. Vitrakoti et al. (2016) Int J Appl Sci Biotechnol, Vol 4(4): 529-536

\begin{tabular}{|c|c|c|c|c|c|c|c|c|c|c|c|}
\hline Genotype & $\begin{array}{l}\text { Days to } \\
\text { Booting }\end{array}$ & $\begin{array}{l}\text { Days to } \\
\text { Heading }\end{array}$ & $\begin{array}{l}\text { Days to } \\
\text { Flowering }\end{array}$ & $\begin{array}{l}\text { Peduncle } \\
\text { Length } \\
\text { (cm) }\end{array}$ & $\begin{array}{l}\text { Spike } \\
\text { Length } \\
\text { (cm) }\end{array}$ & $\begin{array}{l}\text { Plant } \\
\text { Height } \\
\text { (cm) }\end{array}$ & $\begin{array}{l}\text { Flag leaf } \\
\text { area } \\
\left(\mathrm{cm}^{2}\right)\end{array}$ & $\begin{array}{l}\text { Flag leaf }-1 \\
\text { area } \\
\left(\mathrm{cm}^{2}\right)\end{array}$ & $\begin{array}{l}\text { Thousand Grain } \\
\text { Weight } \\
\text { (gm) }\end{array}$ & $\begin{array}{l}\text { Biological } \\
\text { Weight } \\
\text { (kg) }\end{array}$ & $\begin{array}{l}\text { Yield per } \\
\text { hectare } \\
(\mathrm{kg})\end{array}$ \\
\hline $\begin{array}{l}\text { 14-SB-NAK- } \\
\text { MR\#144 }\end{array}$ & 67.00 & 75.58 & 79.45 & 17.31 & 7.46 & 75.66 & 4.70 & 11.76 & 0.05 & 1.50 & 1300 \\
\hline Bonus & 73.00 & 85.35 & 87.13 & 31.44 & 8.34 & 97.17 & 8.65 & 13.57 & 0.06 & 1.45 & 440 \\
\hline Soluuwa & 63.50 & 72.11 & 81.09 & 23.65 & 4.83 & 76.33 & 8.78 & 16.38 & 0.05 & 1.23 & 380 \\
\hline Grand mean & 68.68 & 80.37 & 84.93 & 25.27 & 6.61 & 84.42 & 5.94 & 14.31 & 0.05 & 1.60 & 796.17 \\
\hline F value & $* * *$ & $* * *$ & $* * *$ & $*$ & $*$ & ns & ns & $*$ & $*$ & $*$ & $* * *$ \\
\hline CV(\%) & 3.47 & 3.19 & 3.39 & 15.09 & 18.28 & 9.14 & 56.01 & 31.52 & 15.73 & 21.10 & 31.78 \\
\hline LSD & 4.77 & 5.13 & 5.76 & 7.62 & 2.41 & & & 9.01 & 0.01 & 0.676 & 505.99 \\
\hline
\end{tabular}

Table 3: Simple correlation coefficient of yield components and grain yield per hectare and inter se association of yield components

\begin{tabular}{|c|c|c|c|c|c|c|c|c|c|c|c|}
\hline & $\begin{array}{l}\text { Days to } \\
\text { booting }\end{array}$ & $\begin{array}{l}\text { Days to } \\
\text { heading }\end{array}$ & $\begin{array}{l}\text { Days to } \\
\text { flowering }\end{array}$ & $\begin{array}{l}\text { Peduncle } \\
\text { length }(\mathrm{cm})\end{array}$ & $\begin{array}{l}\text { Spike } \\
\text { length } \\
\text { (cm) }\end{array}$ & $\begin{array}{l}\text { Plant } \\
\text { Height } \\
(\mathrm{cm}) \\
\end{array}$ & $\begin{array}{l}\text { Flag leaf } \\
\text { area }(\mathrm{cm} 2)\end{array}$ & $\begin{array}{l}\text { Flag leaf-1 } \\
\text { Area } \\
(\mathrm{cm} 2) \\
\end{array}$ & $\begin{array}{l}\text { Thousand } \\
\text { Grain weight } \\
\text { (gm) }\end{array}$ & $\begin{array}{l}\text { Biological } \\
\text { weight }(\mathbf{k g})\end{array}$ & $\begin{array}{l}\text { Yield per } \\
\text { hectare } \\
(\mathrm{kg})\end{array}$ \\
\hline Days to booting & 1 & & & & & & & & & & \\
\hline Days to heading & $.858^{* *}$ & 1 & & & & & & & & & \\
\hline Days to flowering & $.792^{* *}$ & $.939^{* *}$ & 1 & & & & & & & & \\
\hline Peduncle length (cm) & $-.150^{\mathrm{ns}}$ & $-.132^{\mathrm{ns}}$ & $-.191^{\mathrm{ns}}$ & 1 & & & & & & & \\
\hline Spike length (cm) & $-.300^{*}$ & $-.221^{\mathrm{ns}}$ & $-.274^{*}$ & $.152^{\mathrm{ns}}$ & 1 & & & & & & \\
\hline Plant Height (cm) & $-.037^{\mathrm{ns}}$ & $-.008^{\mathrm{ns}}$ & $-.126^{\mathrm{ns}}$ & $.682^{* *}$ & $.228^{\mathrm{ns}}$ & 1 & & & & & \\
\hline Flag leaf area $(\mathrm{cm} 2)$ & $.054^{\mathrm{ns}}$ & $.004^{\mathrm{ns}}$ & $-.064^{\mathrm{ns}}$ & $.376^{* *}$ & $-.152^{\mathrm{ns}}$ & $.316^{*}$ & 1 & & & & \\
\hline $\begin{array}{l}\text { Flag leaf-1 Area } \\
(\mathrm{cm} 2)\end{array}$ & $.176^{\mathrm{ns}}$ & $.142^{\mathrm{ns}}$ & $.093^{\mathrm{ns}}$ & $.351^{* *}$ & $-.122^{\mathrm{ns}}$ & $.345^{* *}$ & $.420^{* *}$ & 1 & & & \\
\hline $\begin{array}{l}\text { Thousand } \quad \text { Grain } \\
\text { weight }(\mathrm{gm})\end{array}$ & $-.106^{\mathrm{ns}}$ & $-.244^{\mathrm{ns}}$ & $-.336^{* *}$ & $.042^{\mathrm{ns}}$ & $.054^{\mathrm{ns}}$ & $.231^{\mathrm{ns}}$ & $.034^{\mathrm{ns}}$ & $-.036^{\mathrm{ns}}$ & 1 & & \\
\hline $\begin{array}{l}\text { Biological weight } \\
\text { (kg) }\end{array}$ & $.062^{\mathrm{ns}}$ & $-.001^{\mathrm{ns}}$ & $-.044^{\mathrm{ns}}$ & $.196^{\mathrm{ns}}$ & $.190^{\text {ns }}$ & $.236^{\mathrm{ns}}$ & $.218^{\mathrm{ns}}$ & $.350^{* *}$ & $.153^{\mathrm{ns}}$ & 1 & \\
\hline $\begin{array}{l}\text { Yield per hectare } \\
\text { (kg) }\end{array}$ & $-.663^{* *}$ & $-.761^{* * *}$ & $-.796^{* *}$ & $.229^{\mathrm{ns}}$ & $.310^{*}$ & $.226^{\mathrm{ns}}$ & $.032^{\mathrm{ns}}$ & $-.029^{\mathrm{ns}}$ & $.333^{* *}$ & $.181^{\mathrm{ns}}$ & 1 \\
\hline
\end{tabular}

** $=$ correlation is significant at the 0.01 level (two-tailed), $*=$ correlation is significant at the 0.05 level (two-tailed) and ns $=$ correlation is non-significant. 

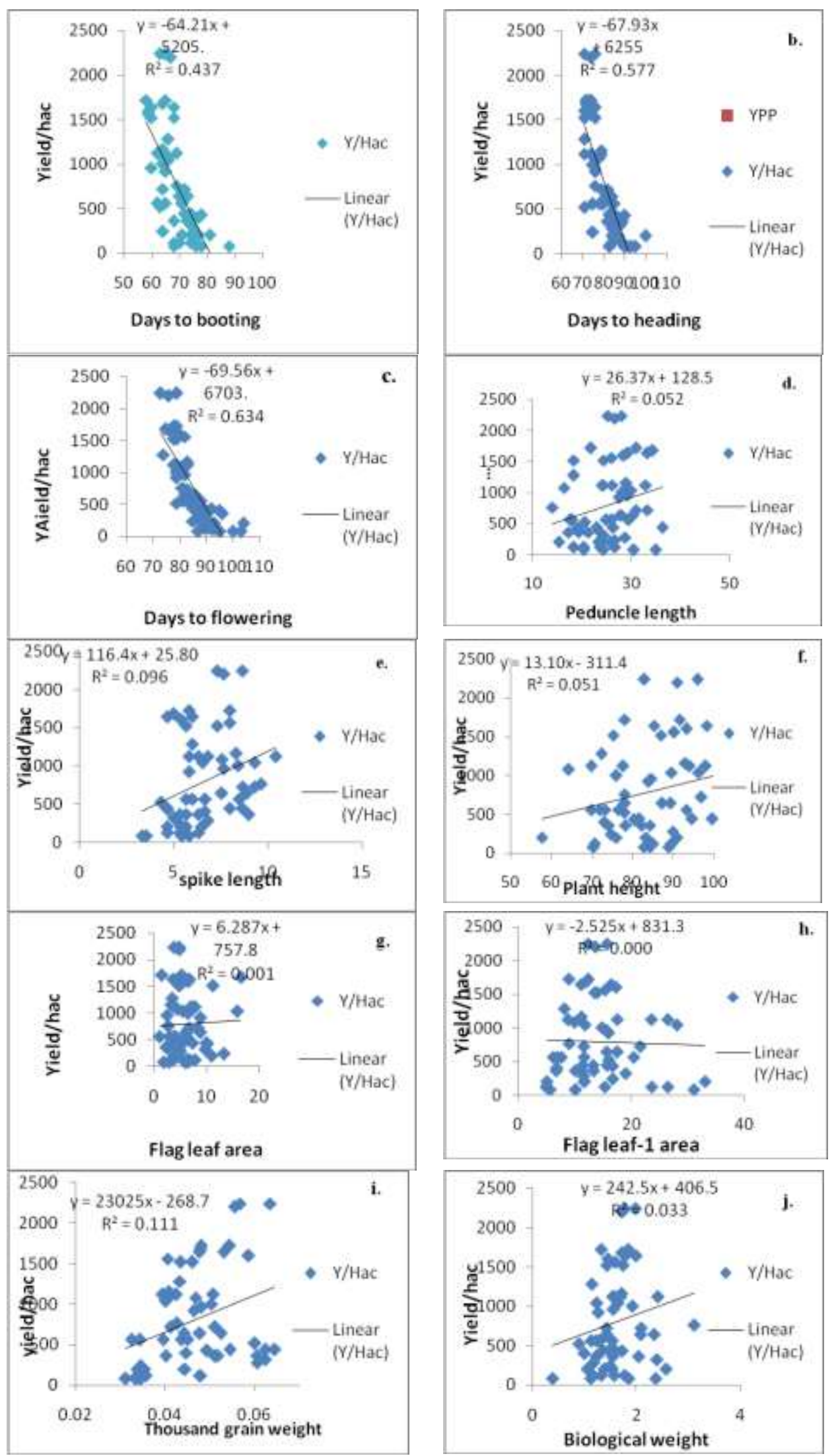

Fig. $1(\mathbf{a}-\mathbf{j})$ : Estimated linear correlation; a. between days to booting and grain yield per hectare $\mathbf{b}$. between days to heading and grain yield per hectare $\mathbf{c}$. between days to flowering and grain yield per hectare $\mathbf{d}$. between peduncle length and grain yield per hectare e. between spike length and grain yield per hectare f. between plant height and grain yield per hectare $\mathbf{g}$. between flag leaf area and grain yield per hectare $\mathbf{h}$. between flag leaf -1 area and grain yield per hectare $\mathbf{i}$. between thousand grain weight and grain yield per hectare $\mathbf{j}$. between biological weight and grain yield per hectare. 
On the contrary, grain yield per hectare had highly significant and and positive correlation with thousand grain weight and significant positive correlation with spike length and non-significant positive correlation with peduncle length, plant height and biological yield. This is supported by similar findings from Chaudhary, (1977), Solanki and Bakshi (1973), Gonzalez et al. (1999), Bhutta et al. (1991), Zadeh et al. (2010), Chutimanitsakun et al. (2011) and Dahleen et al. (2012). Although there exists positive relationship between yield and the other components, the negative correlation between some of them cannot make a useful choice for all as a factor in increasing the yield (Danyard and Kannenberg, 1976).

Besides the correlation observation, the association studies also provide the opportunity to select only those characters which are favorably associated among them as well as with grain yield. In this experiment, studies on inter se association among yield component shows that the trait days to flowering exhibited highly significant positive correlation with other traits viz., days to heading and days to booting and highly significant negative association with grain yield per hectare followed by thousand grain weight and significant negative correlation with spike length.

Similarly thousand grain weight had positive high significant association with grain yield per hectare followed by spike length and negative high significant association with days to flowering followed by days to booting and days to heading and flag leaf- 1 area are negatively correlated and there existed positive correlation with peduncle length, plant height, flag leaf area and biological weight and hence, these traits could be exploited for the improvement of grain yield coupled with earliness using the present materials. Traits table correlation showed that there was a nonsignificant positive correlation between plant height and yield which was quite consistent with the result of the experiment conducted by Drikvaind et al. (2011) in which investigation was done to estimate the correlation of different traits on different variety of barley. Highly significant favorable correlation among yield attributing traits indicates that, the unit increment in one of the trait will cause a unit increment in the another associated traits, which in turn will lead to increase in the grain yield (Sandeepkumar et al., 2011) and hence, these traits could be pointed and noted for the improvement of grain yield by focusing on the associated traits.

\section{Acknowledgement}

The authors would like to express their sincere gratitude ICARDA and HCRP, NARC for the availability of the seeds and to Agriculture and Forestry University, Rampur, Chitwan for the provision of the research field. The authors are highly indebted to Mr. Dipendra Sahi and Mr. Dinesh Khanal for their support and cooperation during the research work. We would like express our gratitude to all the staff members who helped us during our research work.

\section{References}

Akar T, Francia E, Tondelli A, Rizza F, Stanca AM and Pecchioni N (2009) Marker-assisted characterization of frost tolerance in barley (Hordeum vulgare L.). Plant Breeding 128(4): 381-386. DOI: $10.1111 / \mathrm{j} .1439-$ 0523.2008.01553.x

Baniya BK (1989) Present Status of Barley Improvement in Nepal. In a Workshop/Training on Barley, February (Vol. 24).

Baniya BK, Dongol DMS and Riley KW (1997) Characterization of Nepalese barley germplasm. RACHIS (ICARDA).

Bhutta MA, Iqbal J and Sadaqat HA (1991) Correlation and path coefficient analysis of some economic traits in six- rowed barley. J. Anim. Plant. Sci. 1: 171-173.

Chaudhary BD (1977) Variability, correlations and path analysis in barley. Genetics 18: 325-330.

Chutimanitsakun Y, Nipper RW, Cuesta-Marcos A, Cistué L, Corey A, Filichkina T and Hayes PM (2011). Construction and application for QTL analysis of a Restriction Site Associated DNA (RAD) linkage map in barley. BMC genomics 12(1): 1. DOI: 10.1186/1471-2164$12-4$

Dahleen LS, Morgan W, Mittal S, Bregitzer P, Brown RH and Hill NS (2012) Quantitative trait loci (QTL) for Fusarium ELISA compared to QTL for Fusarium head blight resistance and deoxynivalenol content in barley. Plant breeding 131(2): 237-243. DOI: 10.1111/j.14390523.2012.01952.x

Daynard TB and LW Kannenberg (1976) Relationships between Length of the Actual and Effective Grain Filling Period and the Grain Yield of Corn. Can. J. Plant Sci. 56: 237242. DOI: $10.4141 /$ cjps76-038

Drikvand RK, Samiei and Hosseinpor T (2011) Path Analysis Coefficient in Hull -less Barley under Rainfed Condition. Australian Journal of Basic and Applied Sciences. 5(12): 277-279

FAOSTAT (2007) http://faostat.fao.org/site/567/default.aspx; last accessed 7 June 2007.

Feuillet C and Keller B (2002) Comparative genomics in the grass family: molecular characterization of grass genome structure and evolution. Annals of botany 89(1): 3-10. DOI: $10.1093 / \mathrm{aob} / \mathrm{mcf008}$

Gonzalez A, Martin I and Averbe L (1999) Barley yield in heat stress condition and the influence of precocity osmotic adjustment and stomata conductance. Field Crop Res. 62(1): 23-24.

Khayatnezhad MR, Shahriari BR, Gholamin RG, Jamaati-eSomarin S and Zabihi-e-Mahmoodabad R. (2011). Correlation and path analysis between yield and yield components in potato (Solanum tubersum L.). Journal of Scientific Research 7: 17-21.

Mohammadi R, Amri A and Ansari Y (2009) Biplot analysis of rainfed barley multienvironment trials in Iran. Agronomy journal 101(4): 789-796. DOI: 10.2134/agronj2008.0203x 
Moradi M, SoltaniHoveize M and Motamedi M (2010) Path Analysis of Yield and Related Traits in some Wheat Varieties. Research Quarterly Journal of Crop Physiology - Islamic Azad University.Ahvaz Branch. Second Year. Second Issue: 101-107.

Salamini F, Özkan H, Brandolini A, Schäfer-Pregl R and Martin W (2002) Genetics and geography of wild cereal domestication in the Near East. Nature Reviews Genetics 3(6): 429-441.

Sandeepkumar T, Mohan Reddy D, Hariprasad Reddy K. and Sudhakar P (2011) Targeting of traits through assessment of interrelationship and path analysis between yield and yield components for grain yield improvement in single cross hybrids of maize (Zea mays L.). International Journal of Applied Biology and Pharmaceutical Technology 2(3): 123-129.
Singh MK, Pandey RL and Singh RP (1987). Correlation and path coefficient analysis in barley grown on saline soil. Current Agri. 11(1-2): 55-58.

Solanki KR and Bakshi JS (1973). Component characters of grain yield in barley. Indian Journal of Genetics and Plant Breeding 33(2): 201-203.

Steel RG and Torrie JH (1980) Analysis of covariance. Principles and procedures of statistics: A Biometrical Approach, 401437.

Witcombe JR and Gilani MM (1979). Variation in cereals from the Himalayas and the optimum strategy for sampling plant germplasm. Journal of Applied Ecology 633-640. DOI: $10.2307 / 2402537$

Zadeh R, Naderi A and Lakzade A (2010) Effect of Plant Density on Yield and Yield Components of Wheat Genotypes in Different Planting Patterns. Research Quarterly Journal of Crop Physiology. Islamic Azad University of Ahvaz. Second year, first issue. 53-65. 